\title{
BLACK ALDER DOMINATED FOREST VEGETATION IN THE WESTERN PART OF CENTRAL SLOVAKIA - SPECIES COMPOSITION AND ECOLOGY
}

\author{
Richard HRIVNÁK ${ }^{1 *}$, Jaroslav KOŠŤÁL ${ }^{2}$, Michal SLEZÁK ${ }^{1,3}$, \\ Anna PETRÁŠOVÁ ${ }^{4} \&$ Melánia FESZTEROVÁ ${ }^{5}$
}

\begin{abstract}
In some regions of Slovakia, black alder forest vegetation has not been documented appropriately yet. This paper is the first vegetation study presenting the phytosociological data and measured environmental parameters from the western part of central Slovakia. The data set was classified by using a modified TWINSPAN algorithm, which allowed us to discern floristically and ecologically distinctive plant communities. They correspond to the associations Stellario nemorum-Alnetum glutinosae Lohmeyer 1957 (riparian alder vegetation on mesic to humid sites along small brooks) and Carici acutiformis-Alnetum glutinosae Scamoni 1935 (eutrophic black alder carr forests in the colline zone) with the variants of Ligustrum vulgare and Galium palustre. The community Carici elongatae-Alnetum glutinosae Schwickerath 1933 (mesotrophic to eutrophic alder carr vegetation growing on permanently waterlogged soils), documented only with two phytosociological relevés, was distinguished following expert knowledge. A floristic and ecological pattern of these associations is presented. The major compositional gradients were interpreted based on Ellenberg's indicator values and the values of environmental variables recorded during the field sampling in the growing season 2011. The principal component analysis revealed the importance of soil moisture, light availability, portion of open water and soil surface for species composition variability at the association level, whereas the variants of Carici acutiformis-Alnetum glutinosae were sorted along the acidity gradient.

Key words: Alnion glutinosae, Alnion incanae, Ellenberg indicator values, forest vegetation, soil variables, syntaxonomy.

\section{Izvleček}

Gozdna vegetacija črne jelše dosedaj v nekaterih predelih Slovaške še ni bila dovolj raziskana. Članek predstavlja prvo vegetacijsko raziskavo fitocenoloških popisov in merjenih rastiščnih dejavnikov iz zahodnega dela osrednje Slovaške. Podatkovni niz smo klasificirali z modificiranim TWINSPAN algoritmom, s čemer smo lahko floristično in ekološko ločili značilne rastlinske združbe. Ugotovili smo asociaciji: Stellario nemorum-Alnetum glutinosae Lohmeyer 1957 (obvodna črnojelševja na srednje do vlažnih rastiščih ob manjših potokih) in Carici acutiformis-Alnetum glutinosae Scamoni 1935 (evtrofna črnojelševja v kolinskem pasu) z dvema variantama Ligustrum vulgare in Galium palustre. Asociacijo Carici elongatae-Alnetum glutinosae Schwickerath 1933 (mezotrofni do eutrofni črnojelševi grezi, ki uspevajo na tleh stalno prepojenih z vodo), ki je dokumentirana samo z dvema popisoma smo določili na podlagi strokovnega poznavanja.

Prikazali smo floristični in ekološki vzorec pojavljanja teh asociacij. Glavni gradienti so pojasnjeni na podlagi Ellenbergovih indikatorskih vrednosti, ekološki dejavniki pa so bili merjeni med terenskim vzorčenjem v vegetacijski sezoni 2011. Analiza glavnih komponent je razkrila pomen vlažnosti tal, svetlobe, deleža odprtih vodnih in talnih površin za variabilnost vrstne sestave na nivoju asociacij, medtem ko se varianti asociacije Carici acutiformis-Alnetum glutinosae ločita na gradientu kislosti.
\end{abstract}

Ključne besede: Alnion glutinosae, Alnion incanae, Ellenbergove indikatorske vrednosti, gozdna vegetacija, talne spremenljivke, sintaksonomija.

\footnotetext{
${ }^{1}$ Institute of Botany, Slovak Academy of Sciences, Dúbravská cesta 9, SK-845 23 Bratislava, Slovak Republic; e-mail: richard.hrivnak@savba.sk;

${ }^{2}$ State Nature Conservancy of Slovak Republic, Samova 3, SK-949 01 Nitra, Slovak Republic; e-mail: kostaljar@gmail.com
} 


\section{INTRODUCTION}

Forest vegetation with dominance of black alder (Alnus glutinosa (L.) Gaertn.) is common on swampy soils with high groundwater table, or it creates more mesophilous stands in alluvial zones along rivers and brooks (Oberdorfer 1953, Douda 2008, Ellenberg 2009, Sburlino et al. 2011). The understorey of these forests in general consists of species having diverse moisture-requirements. It is composed of either mesophilous forest plants or marshland and wet species. Apparent environmental differentiation, considerable floristical variability and inconsistent physiognomy indicate existence of various alder forests with different syntaxonomical positions. At the level of phytosociological alliances, the major types of alder vegetation include hygro- or meso-hygrophilous streamside forests (Alnion incanae, class QuercoFagetea) and alder carr forests (Alnion glutinosae, class Alnetea glutinosae).

The syntaxonomical concept of two separate alliances has also been recognized in the central Slovak synthesis (Slezák et al. 2013) representing a preliminary revision of alder vegetation in Slovakia. It uses a more formalized classification method (cf. Chytrý 2000) and provides further evidence for uneven distribution of phytosociological material in Western Carpathians. Except for few vegetation analyses (Šomšák 1961, Kárpáti et al. 1963, Miadok 1978, Balázs 1996), most of the relevés collected in the past were published in local studies containing not only data of alderdominated forests (e.g. Berta 1970, NeuhäuslováNovotná 1970, Kontriš 1981). Recently, there has arisen an increased interest in many aspects of their syntaxonomy and synecology (Šomšák 2000, Kollár et al. 2005, Hrivnák et al. 2009, Slezák et al. 2011, 2013). Petrášová et al. (2011) devoted a special attention to a detailed analysis of bryophyte species composition, as the moss layer plays an important role in the community structure of these vegetation types. Local phytosociological studies offering new relevés are thus significant tool for compilation of national data set, as there are still territories without any or with only few available relevés. This was primary reason for investigation of alder forest variability in the Ponitrie region (Figure 1) which is characterized only by negligible and descriptive information about such vegetation (cf. Eliáš 1980, 2008). The purpose of our vegetation study was (i) to identify the main types of alder forests in the study area by field sampling and numerical analysis, and (ii) to find environmental drivers responsible for variation in their species composition.

\section{METHODS}

We studied black alder dominated forests in the western part of central Slovakia (Ponitrie region; Figure 1) following the principles of the Zürich-Montpellier approach (Westhoff \& van der Maarel 1973). Phytosociological sampling of 19 vegetation plots was carried out in valleys consisting of diverse geological substrates in 2011. The cover of vascular plants and bryophytes was recorded using the Braun-Blanquet sampling scale extended by Barkman et al. (1964). Phytosociological relevés were stored in a TURBOVEG database (Hennekens \& Schaminée 2001) and exported into Juice program (Tichý 2002). Modified TWINSPAN algorithm (Roleček et al. 2009) was run for numerical classification with three pseudospecies cut levels $(0 \%, 5 \%, 25 \%)$ and total inertia as a measure of cluster heterogeneity. The TWINSPAN division was accepted at the 3-cluster level following the outcomes of crispness curve method (Botta-Dukát et al. 2005). This partition produced clusters which closely matched the established phytosociological units. The same species recorded in various layers (herb $-\mathrm{E}_{1}$, shrub $-\mathrm{E}_{2}$ and tree $-\mathrm{E}_{3}$ ) were merged prior to the analysis. Lists of diagnostic species for individual clusters were derived on the basis of frequency concept, i.e. the species considered as diagnostic needed to display a frequency above $50 \%$ in particular cluster, and the difference in frequencies among the clusters more than $40 \%$. Two relevés

\footnotetext{
${ }^{3}$ Faculty of Education, Catholic University, Hrabovská cesta 1, SK-034 01 Ružomberok, Slovak Republic; e-mail: slezak. miso@gmail.com

${ }^{4}$ Faculty of Natural Sciences, Matej Bel University, Tajovského 40, SK-974 01 Banská Bystrica, Slovak Republic; e-mail: anniepetrasov@gmail.com

${ }^{5}$ Faculty of Natural Sciences, Constantine the Philosopher University in Nitra, A. Hlinku 1 SK-94901 Nitra; Slovak Republic; e-mail: mfeszterova@ukf.sk

* Corresponding author.
} 
with partially outlying species composition (codominance of Carex elongata in the herb layer), which were merged with the floristically closest cluster in the numerical classification, were arbitrarily arranged in the text in order to simplify the results. The expert knowledge was used for their syntaxonomical interpretation. Subsequently, all the next analyses were performed without them.

The species-environmental relationships were quantified and tested by the linear ordination method (Principal component analysis; PCA) in CANOCO for Windows 4.5 package (ter Braak \& Šmilauer 2002), as the length of gradient in the Detrended correspondence analysis was $2.56 \mathrm{SD}$ units. Non-weighted Ellenberg indicator values (EIV) for vascular plants (Ellenberg et al. 1992) and selected environmental data (see Table 1) for relevés were plotted into the PCA ordination diagrams as supplementary variables and correlated to the relevé scores on the first two ordination axes using the Pearson correlation coefficient. The one-way ANOVA and post-hoc Tukey HSD test was applied for multiple comparisons of environmental parameters in the STATISTICA software (StatSoft 2001).

Soil samples were randomly taken in three places in sampling plot from the uppermost mineral horizon (0-10 cm depth, litter removed) and mixed to form a single sample per plot in order to reduce the soil heterogeneity. They were dried at a laboratory temperature, crushed and passed through a $2 \mathrm{~mm}$ sieve (Slezák et al. 2011). Soil pH

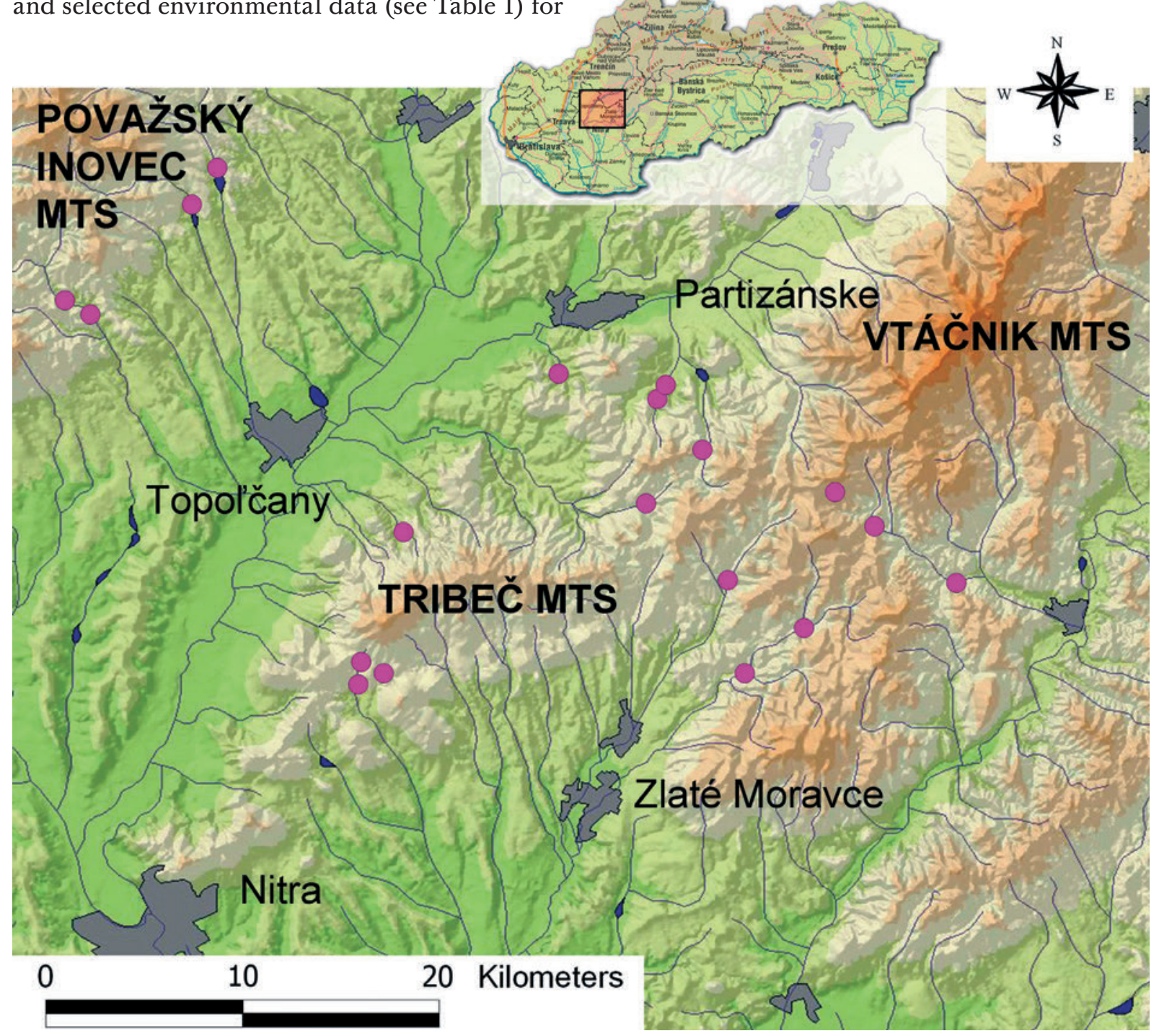

Figure 1: Distribution of phytosociological relevés of alder-dominated forests in the western part of central Slovakia. Slika 1: Porazdelitev fitocenoloških popisov gozdov v katerih dominira črna jelša v zahodnem delu osrednje Slovaške. 

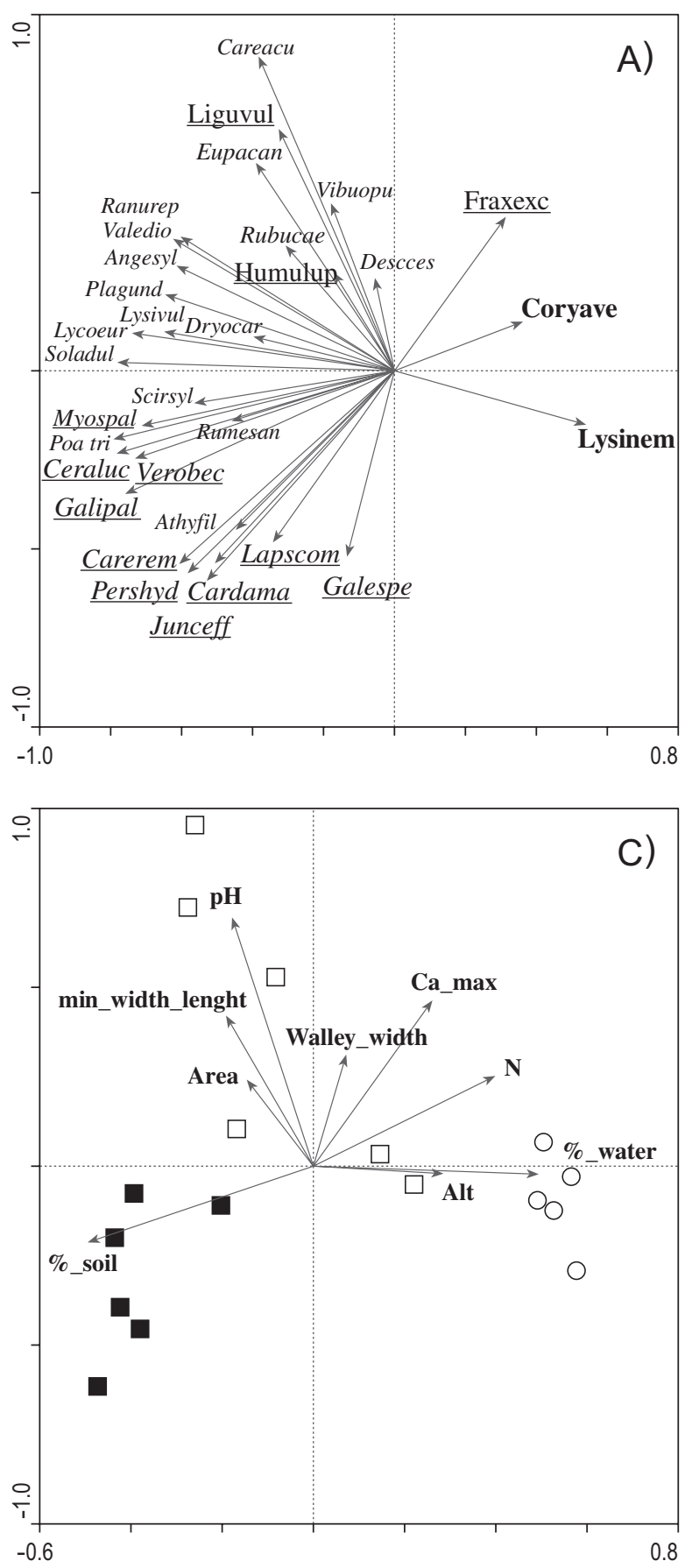

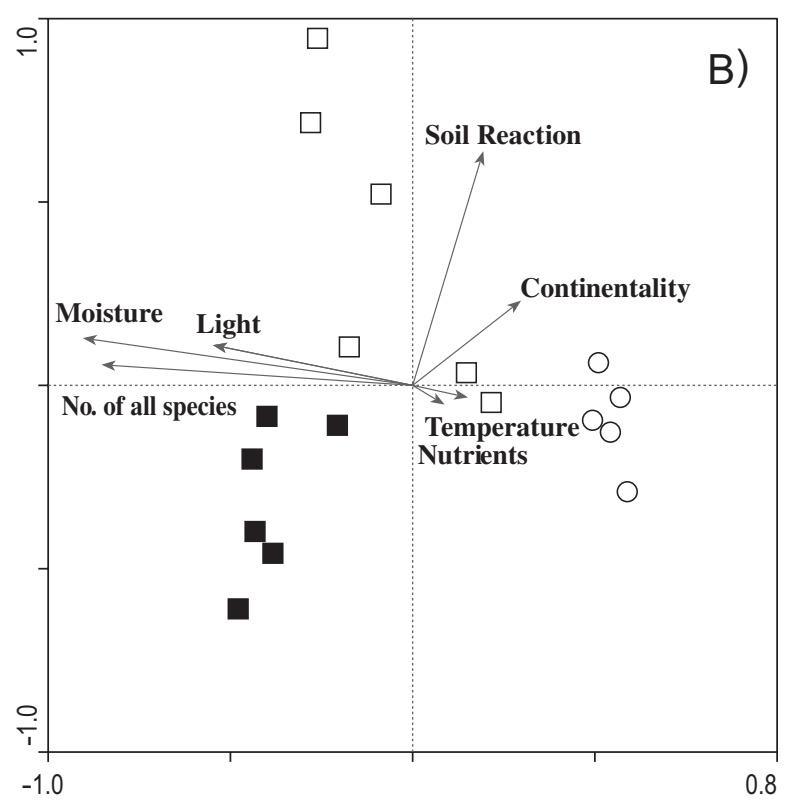

Figure 2: PCA ordination diagrams. The first two ordination axes explain $22.6 \%$ and $13.5 \%$ of the total species variability. A) Distribution of diagnostic species for particular units in ordination space (normal bold - Stellario nemorum-Alnetum glutinosae; italic - Carici acutiformis-Alnetum glutinosae, underline normal - variant with Ligustrum vulgare, underline italic - variant with Galium palustre); B, C) Position of sampling sites with environmental factors (EIV, number of all species - B; directly measured or calculated factors - C) displayed as supplementary variables. Empty circles - Stellario nemorum-Alnetum glutinosae, squares - Carici acutiformisAlnetum glutinosae (empty squares - variant with Ligustrum vulgare, full squares - variant with Galium palustre).

Slika 2: PCA ordinacijski diagram. Prvi dve osi pojasnita $22,6 \%$ in $13,5 \%$ skupne variabilnosti vrst. A) Razširjenost značilnih vrst določenih enot $\mathrm{v}$ ordinacijske prostoru (običajno krepko - Stellario nemorum-Alnetum glutinosae; poševno - Carici acutiformis-Alnetum glutinosae, običajno podčrtano - varianta $\mathrm{z}$ Ligustrum vulgare, podčrtano poševno - varianta z Galium palustre); B, C) Položaj vzorčenih sestojav z rastiščnimi dejavniki (EIV, število vseh vrst - B; neposredno merjeni ali izračunani- C) prikazano kot dopolnilne spremenljivke. Prazni krožci - Stellario nemorum-Alnetum glutinosae, kvadrati - Carici acutiformis-Alnetum glutinosae (prazni kvadrati - varianta z Ligustrum vulgare, polni krožci varianta z Galium palustre).

Abbreviations of species names and environmental variables (Okrajšava imen vrst in ekoloških dejavnikov): Angesyl - Angelica sylvestris, Athyfil - Athyrium filix-femina, Cardama - Cardamine amara, Careacu - Carex acutiformis, Carerem - Carex remota, Ceraluc - Cerastium lucorum, Coryave - Corylus avellana, Descces - Deschampsia cespitosa, Dryocar - Dryopteris carthusiana, Eupacan - Eupatorium cannabinum, Fraxexc - Fraxinus excelsior, Galespe - Galeopsis speciosa, Galipal - G. palustre, Humulup - Humulus lupulus, Junceff - Juncus effusus, Lapscom - Lapsana communis, Liguvul - Ligustrum vulgare, Lycoeur - Lycopus europaeus, Lysinem - Lysimachia nemorum, Lysvulg - L. vulgaris, Myospal - Myosotis scorpioides agg., Pershyd - Persicaria hydropiper, Plagund - Plagiomnium undulatum, Poa tri - P. trivialis, Ranurep - Ranunculus repens, Scirsyl - Scirpus sylvaticus, Rubucae - Rubus caesius, Rumesan - Rumex sanguineus, Soladul - Solanum dulcamara, Valedio - Valeriana dioica, Verobec - Veronica beccabunga, Vibuop - Viburnum opulus; Ca_max - maximum concentration of calcium in soil solution, Min_width_ lenght - minimum width or length of the studied stands, \%_soil - percentage of open soil, \%_water - percentage of open water. 
was measured in a distilled water solution (soil/ water ratio of $1 / 2.5$ ) and inorganic $\mathrm{N}$ content as sum of $\mathrm{N}-\mathrm{NH}_{4}{ }^{+}$and $\mathrm{N}-\mathrm{NO}_{3}{ }^{-}$(extracted with $\mathrm{K}_{2} \mathrm{SO}_{4}$ and determined colorimetrically using a Nessler's reagent and acid phenoldihydrosulphate, respectively). Calcium content was extracted in $10 \%$ $\mathrm{HCl}$ solution and determined in accordance with the recommendation by Šimanský (2010).

Altitude and geographical coordinates (WGS 84) were measured in the field with GPS equipment. Percentage cover of open soil (without any vegetation) and open water areas was estimated visually in the field. Since several recent studies have shown the pronounced effect of habitat quality and landscape configuration-related factors on species composition pattern in floodplain forests and/or alder-dominated vegetation (e.g. Hérault \& Honnay 2005, Douda 2010, Košir et al. 2013), total area, minimal width or length of the studied alder forests in each sampling site and width of the valley were obtained from GIS layers as well.

The nomenclature of bryophytes and vascular plants follows the checklist by Marhold \& Hindák (1998). The names of plant communities and their assignment into the higher units are in accordance with Jarolímek et al. (2008). Full scientific name of vegetation units with the author's name and year of description were used in case when they were not presented in the above-mentioned paper.

\section{RESULTS}

\section{SPECIES COMPOSITION PATTERNS}

Numerical classification led to delimitation of two main relevé's groups that correspond to the associations of Stellario nemorum-Alnetum glutinosae (cluster A) and Carici acutiformis-Alnetum glutinosae (cluster B; Table 2). They are characterized by distinctive floristic composition with clearly defined lists of diagnostic species. While mesophilous or slightly hygrophilous species are related to the stands of the cluster A, hygrophilous and marshland plants are typical for the forests of cluster B (Table 2). The second level of TWINSPAN division separated relevés of cluster $\mathrm{B}$ into two floristically well-differentiated variants, namely variant with Ligustrum vulgare and variant with Galium palustre. Similar patterns in composition structure of data set were also found in the ordination analysis (Figure 2).
Forest stands recorded within the association Stellario nemorum-Alnetum glutinosae are usually three-layered. The canopy closed tree layer is almost exclusively created by Alnus glutinosa, whereas the shrub layer is most often built up by Acer campestre and Corylus avellana (Table 2). The forest understorey contains species typical for various environmental microhabitats. In more detail, forest mesophilous plants (e.g. Brachypodium sylvaticum, Circaea lutetiana, Pulmonaria officinalis agg.) constantly grow in combination with more or less hygrophilous (e.g. Caltha palustris, Impatiens noli-tangere) and nitrophilous species (Aegopodium podagraria, Galium aparine, Glechoma hederacea, Urtica dioica; Table 2, Figure 2a). The physiognomy of herb layer is determined by dominant presence of the Urtica dioica. Other species such as Glechoma hederacea and Petasites hybridus reach higher cover values only occasionally (Figure 3). Higher frequency is charac-

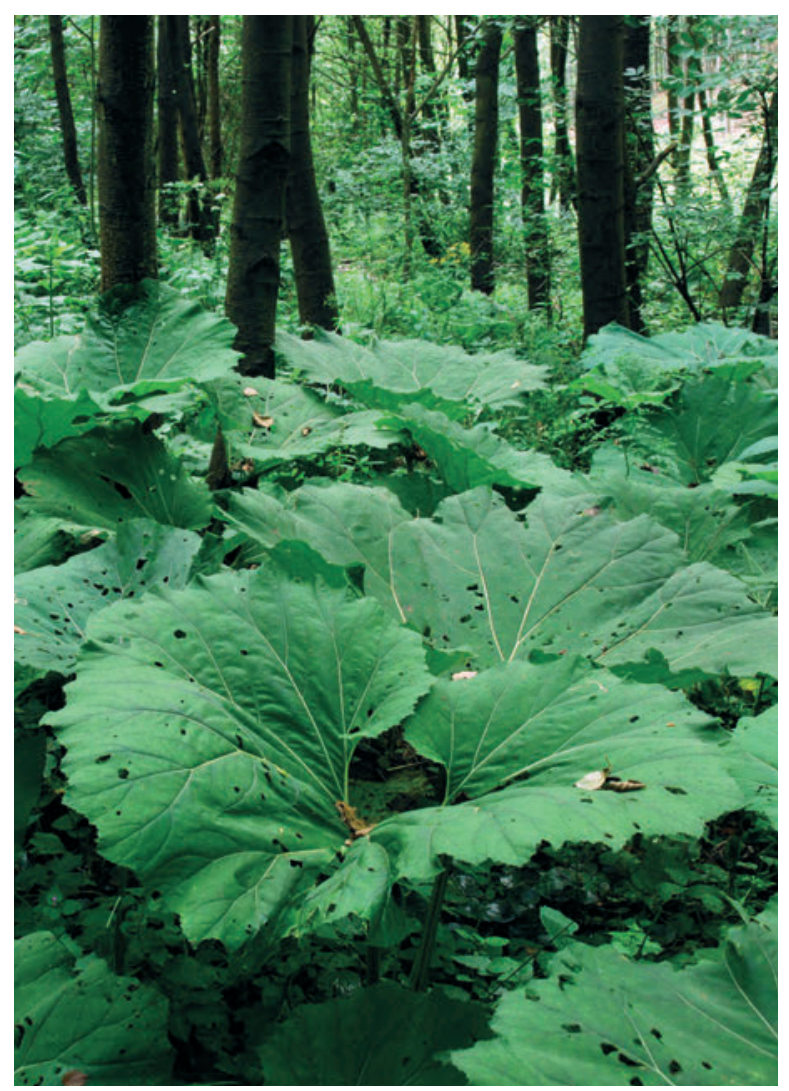

Figure 3: Mesophilous streamside forests with dominant species Petasites hybridus (Photo: J. Koštál, 19. 07. 2011, Vel'ké Pole - Tomov štál).

Slika 3: Mezofilni gozdovi ob vodotokih s prevladujočo vrsto Petasites hybridus (Foto: J. Koštál, 19. 07. 2011, Vel'ké Pole Tomov štál). 
teristic for mosses Brachythecium rutabulum and Eurhynchium hians. The species richness of this community, ranging from 29 to 52 species with a mean of 40 taxa per relevé, is significantly lower than the species number in both variants of $\mathrm{Ca}$ rici acutiformis-Alnetum glutinosae (Table 1 ).

The conspicuous feature in vertical structure of the community Carici acutiformis-Alnetum glutinosae is the homogenous tree layer composed of Alnus glutinosa and the species-rich shrub layer (Table 2). The floristic spectrum depends on specific environmental conditions which are suitable especially for numerous hygrophilous and marshland species, including Angelica sylvestris, Caltha palustris, Carex remota, Lycopus europaeus, Lysimachia vulgaris, Myosotis scorpioides agg., Poa trivialis and Solanum dulcamara. The tall-sedge Carex acutiformis together with Impatiens noli-tangere and Caltha palustris most often alternate as dominant species in the forest understorey ( $\mathrm{Ta}-$ ble 2, Figure 4). Unlike the constant water-toler- ant species, mesophilous plants are presented only with lower frequency. In addition to the regular occurrence of species Plagiomnium undulatum, moss layer is locally formed by generalists of wet habitats (e.g. Atrichum undulatum, Plagiomnium affine s. lat.). In accord with the species composition pattern, we distinguished two alder forests at the level of variants. The Carici acutiformis-Alnetum glutinosae variant with Ligustrum vulgare consists of species-rich shrub layer including mainly species such as Acer campestre, Fraxinus excelsior, Ligustrum vulgare, Prunus spinosa and Swida sanguinea, whereas the stands of variant with $\mathrm{Ga}$ lium palustre encompass only weakly developed shrub layer. On the other hand, the herb layer of latter one is also enriched with ferns (Athyrium filix-femina, Dryopteris spec. div.) and moisturedemanding species (e.g. Cardamine amara, funcus effusus, Persicaria hydropiper). These variants are equally species-rich with means of 58 and 63 taxa per relevé, respectively (Table 1 ).

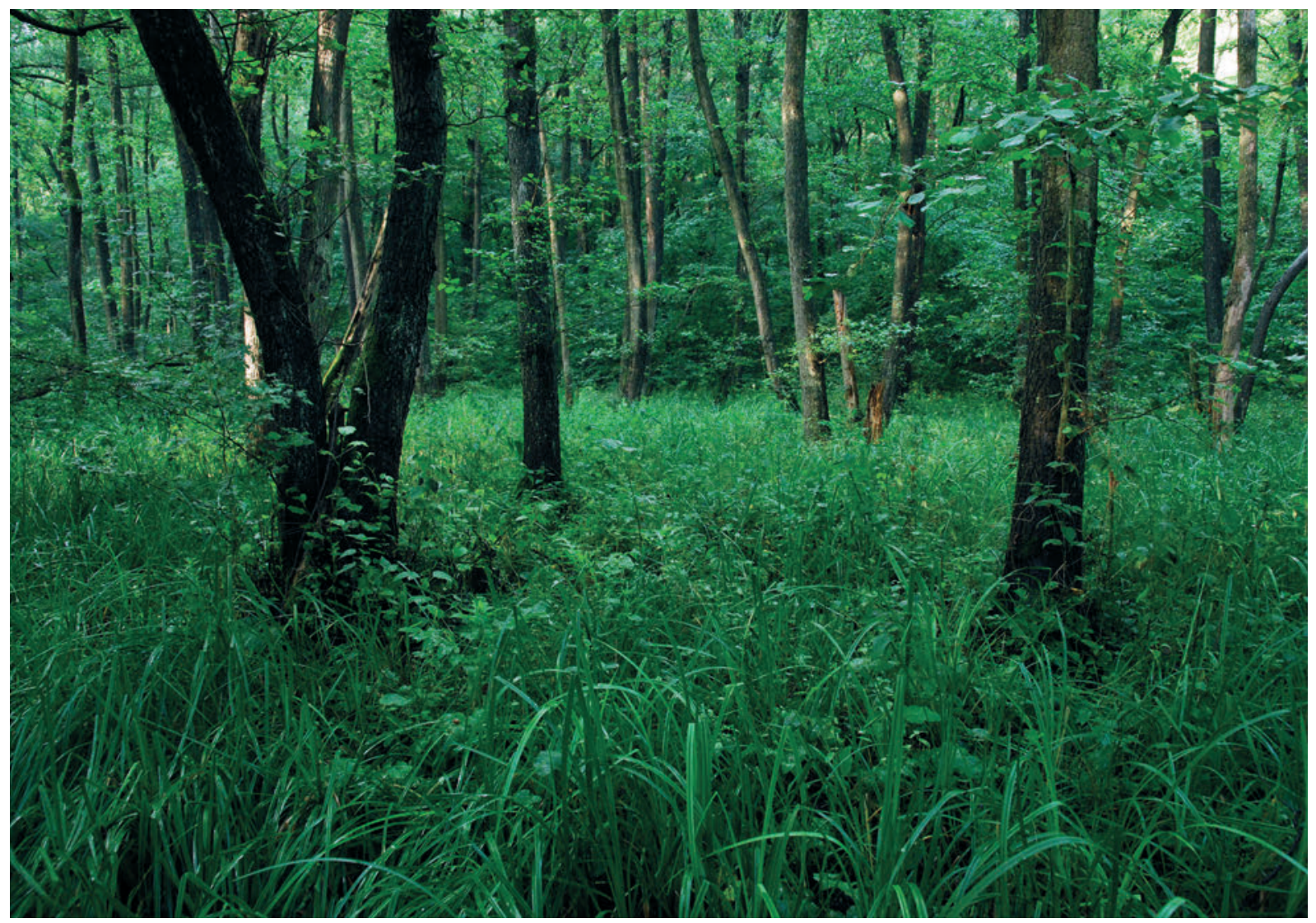

Figure 4: Physiognomy of forest understorey in the community of Carici acutiformis-Alnetum glutinosae created by Carex acutiformis (Photo: J. Koštál, 22. 07. 2011, Tesáre).

Slika 4: Fizionomija zeliščne plasti asociacije Carici acutiformis-Alnetum glutinosae, kjer prevladuje Carex acutiformis (Foto: J. Koštál, 22. 07. 2011, Tesáre). 
Alder carr forests with dominant Carex elongata are documented only with two phytosociological relevés given below. They exclusively settle waterlogged soils. Species composition of these stands reflects typical microrelief heterogeneity (Figure 5), i.e. species adapted to waterlogged hollows and species showing affinity to hummocks are accompanied by plants of wet meadows along with liana elements. This species combination supports their assignment into the association Carici elongatae-Alnetum glutinosae.

Relevé I, Jedlové Kostolany, Žitava river at the mouth of the Osná valley (Tribeč Mts.), altitude $320 \mathrm{~m}$, area $400 \mathrm{~m}^{2}$, cover $\mathrm{E}_{3} 85 \%, \mathrm{E}_{2} 2 \%, \mathrm{E}_{1} 95 \%, \mathrm{E}_{0} 5 \%, 18^{\circ} 29^{\prime} 54.29 " \mathrm{E}$, $48^{\circ} 27^{\prime} 05.86^{\prime \prime} \mathrm{N}$, date 09. 07. 2011, author J. Koštál.

$\mathrm{E}_{3}$ : Alnus glutinosa 5 .

$\mathrm{E}_{2}$ : Fraxinus excelsior +, Viburnum opulus +, Acer campestre $\mathrm{r}$, A. pseudoplatanus r, Crataegus monogyna $\mathrm{r}$, Ligustrum vulgare $\mathrm{r}$, Sambucus nigra $\mathrm{r}$.
$\mathrm{E}_{1}$ : Caltha palustris 3, Carex elongata 3, Thelypteris palustris 2b, Carex appropinquata 2a, Crepis paludosa 2a, Impatiens parviflora 2a, Carex remota 1, Dryopteris carthusiana 1, Equisetum arvense 1, Impatiens nolitangere 1, Lycopus europaeus 1, Lysimachia vulgaris 1, Solanum dulcamara 1, Alnus glutinosa + , Athyrium filix-femina + , Bidens frondosus +, Brachypodium sylvaticum + , Cardamine amara + , Circaea lutetiana + , Dryopteris dilatata + , Epilobium tetragonum subsp. tetragonum +, Festuca gigantea +, Filipendula ulmaria +, Galium palustre +, Humulus lupulus +, Myosotis scorpioides agg. + , Poa trivialis + , Ranunculus repens + , Rubus idaeus + , Scirpus sylvaticus + , Viburnum opulus +, Acer pseudoplatanus r, Angelica sylvestris r, Deschampsia cespitosa r, Dryopteris filix-mas r, Euonymus europaeus $r$, Melica uniflora $r$, Poa nemoralis $\mathrm{r}$, Rumex sanguineus $\mathrm{r}$, Stellaria nemorum $\mathrm{r}$, Swida sanguinea $\mathrm{r}$, Veronica beccabunga $\mathrm{r}$.

$\mathrm{E}_{0}$ : Plagiothecium denticulatum 1, Atrichum undulatum + , Brachythecium rutabulum +, Herzogiella seligeri $\mathrm{r}$, Lophocolea heterophylla $\mathrm{r}$.

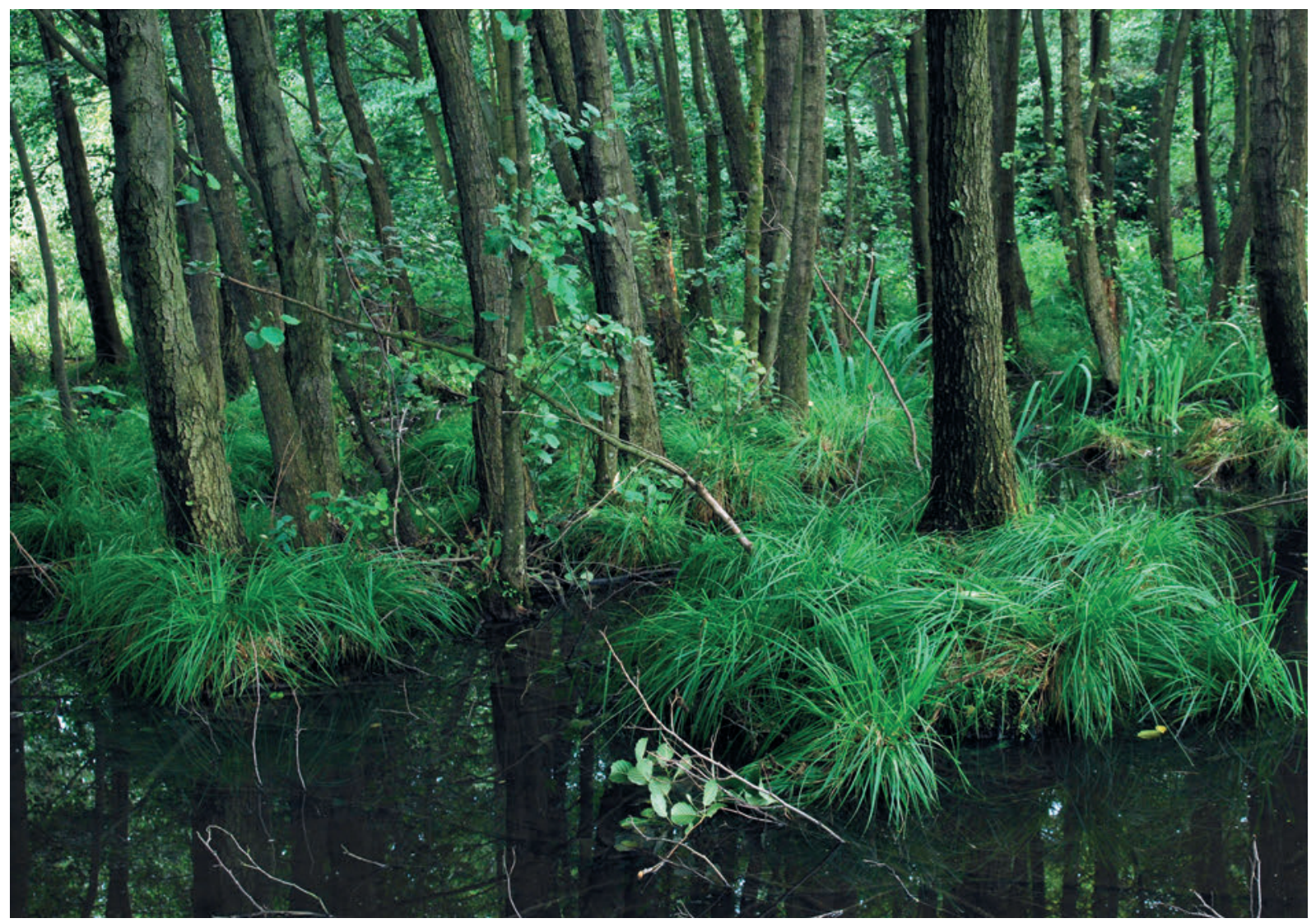

Figure 5: Microrelief heterogeneity in alder carr forests of Carici elongatae-Alnetum glutinosae with presence of hummocks and stagnant water on soil surface in hollows (Photo: J. Koštál, 22. 07. 2011, Nemečky).

Slika 5: Mikroreliefna heterogenost v črnojelševem grezu Carici elongatae-Alnetum glutinosae z grbinami dvignjenimi nad stoječo vodo (Foto: J. Koštál, 22. 07. 2011, Nemečky). 
Relevé II, Nemečky, water reservoir (Považský Inovec Mts.), altitude $282 \mathrm{~m}$, area $400 \mathrm{~m}^{2}$, cover $\mathrm{E}_{3} 90 \%, \mathrm{E}_{2} 5 \%, \mathrm{E}_{1}$ $50 \%, \mathrm{E}_{0} \%, 18^{\circ} 06^{\prime} 36.68^{\prime \prime} \mathrm{E}, 48^{\circ} 41^{\prime} 09.43^{\prime \prime} \mathrm{N}$, date 22.07. 2011, author J. Koštál.

$\mathrm{E}_{3}$ : Alnus glutinosa 5 .

$\mathrm{E}_{2}$ : Alnus glutinosa + , Padus avium $\mathrm{r}$, Salix fragilis $\mathrm{r}$.

$\mathrm{E}_{1}$ : Carex elongata 3, Carex remota $2 \mathrm{a}$, Iris pseudacorus 1 , Lycopus europaeus 1, Lysimachia vulgaris 1, Scirpus sylvaticus 1, Solanum dulcamara 1, Callitriche sp. +, Caltha palustris + , Carex acutiformis + , C. canescens,+ Deschampsia cespitosa +, Filipendula ulmaria +, Galium palustre +, Glyceria fluitans + , Impatiens noli-tangere + , I. parviflora +, Juncus effusus +, Lemna minor + , Lysimachia nummularia +, Myosotis scorpioides agg. +, Phalaroides arundinacea + , Ranunculus repens + , Athyrium filix-femina r, Calystegia sepium r, Cardamine amara r, Circaea lutetiana r, Equisetum arvense r, Festuca gigantea r, Fraxinus excelsior r, Galeopsis speciosa r, Glechoma hederacea r, Poa palustris r, Poa trivialis r, Quercus robur r, Rubus idaeus r, Salix fragilis r, Stachys sylvatica $\mathrm{r}$, Urtica dioica $\mathrm{r}$.

$\mathrm{E}_{0}$ : Atrichum undulatum + , Brachythecium rutabulum + , Hypnum cupressiforme +, Plagiomnium undulatum + .

Syntaxonomical scheme of the documented alder forests is:

Class: Alnetea glutinosae Br.-Bl. et R. Tx. ex Westhoff et al. 1946

Order: Alnetalia glutinosae R. Tx. 1937

Alliance: Alnion glutinosae Malcuit 1929

Association: Carici acutiformis-Alnetum glutinosae Scamoni 1935

variant with Ligustrum vulgare

variant with Galium palustre

Association: Carici elongatae-Alnetum glutinosae Schwickerath 1933

Class: Querco-Fagetea Br.-Bl. et Vlieger in Vlieger 1937

Order: Fagetalia Pawłowski in Pawłowski et al. 1928

Alliance: Alnion incanae Pawłowski in Pawłowski et al. 1928

Association: Stellario nemorum-Alnetum glutinosae Lohmeyer 1957

\section{ENVIRONMENTAL CONDITIONS}

Statistically significant $(P<0.05)$ Pearson correlations with the first PCA ordination axis stressed the role of EIV for moisture $(r=-0.86)$, light $(r=-0.84)$, portion of open water in soil surface $(r=0.50)$ and portion of soil surface without any vegetation $(r=-0.49)$. Based on this evidence, the left side of the ordination diagram with higher moisture- and light-requirements was occupied by relevés of Carici acutiformis-Alnetum glutinosae (cluster B), whereas stands of Stellario nemorumAlnetum glutinosae (cluster A) having inverse the above-mentioned values were concentrated in the opposite end (Figure 2b, c). The second PCA axis can be interpreted as an acidity gradient (Figure 2c) following the strongest positive correlation with the soil $\mathrm{pH}(r=0.69, P<0.01)$. Along this axis, there were scattered especially relevés of particular variants of the Carici acutiformis-Alnetum glutinosae. Multiple comparisons indicated only slight differences in environmental factors (Table 1), but they mostly coincided with the main gradients governing species composition in alder forest vegetation (Figure 2b, c). Alder carr forests confirmed expected relation on more hygrophilous sites with higher portion of open soil surface than riparian streamside vegetation of Stellario nemorum-Alnetum glutinosae.

\section{DISCUSSION}

The present study emphasized floristical and environmental differentiation of alder plant communities. The identified forest vegetation types belong to either alder carr forests of Carici acutiformis-Alnetum glutinosae and Carici elongatae-Alnetum glutinosae (Alnion glutinosae) or mesophilous floodplain forests of Stellario nemorum-Alnetum glutinosae (Alnion incanae). They differ in the species composition and in several ecological characteristics, e.g. water regime, soil properties and microrelief heterogeneity. Alder carr forests grow on permanently waterlogged soils with stagnant or very slow flowing water on soil surface (Ellenberg 2009). These conditions are favourable for occurrence of numerous moisture-demanding species including the marshland plants, spring specialists and common species of wet habitats (Table 2). The higher light-requirements of the $A l$ nion glutinosae vegetation (Figure $2 \mathrm{~b}$ ) can be similarly addressed to the heavy and swampy soils, as these edaphic properties naturally control mosaic structure of the tree layer permitting more light penetration through the canopy (Douda 2008, Slezák et al. 2011). Analogous sites also showed higher portion of soil surface without any vegeta- 
R. Hrivnák et al.: Black alder Dominated Forest Vegetation in the Western Part of Central Slovakia ...

tion (Table 1) what can be attributed to partial decline of water table in sampling period. In spite of such water fluctuation, soils remain still sufficiently moist. Although the significant impact of soil reaction on variability of alder forests has already been proven by Douda (2008), acidity gradient was important environmental driver only for delimitation of two variants within Carici acutiformis-Alnetum glutinosae in study region.

The unsupervised method of numerical classification (cf. Černá \& Chytrý 2005) did not split meso- to eutrophic alder carr vegetation growing on periodically waterlogged soils (Carici elongatae-Alnetum glutinosae) from eutrophic black alder carr forests confined to colline areas ( $\mathrm{Ca}$ rici acutiformis-Alnetum glutinosae). This mergence most likely results from small number of relevés with dominance of Carex elongata in the analysed data set. Both of these vegetation types belong to commonly recorded alder carr forests in Slovakia (e.g. Balázs 1996, Šomšák 2000, Kollár et al. 2005, Slezák et al. 2011). Plant communities with similar floristic structure and habitat preference are known from several Central European countries (Pott 1992, Neuhäuslová 2000, Willner \& Grabherr 2007, Borhidi et al. 2012). Eutrophic black alder stands of low-lying damp and marshland localities have also been reported from the Pannonian Basin (Szmorad 2011, Borhidi et al. 2012) and adjacent regions in the Western Carpathians (Kliment \& Watzka 2000) as Angelico sylvestrisAlnetum glutinosae. To achieve reliable resolution of its syntaxonomical position within the alliance Alnion glutinosae in Central European context and to clarify its relationship to Carici acutiformisAlnetum glutinosae, phytosociological synthesis of large-scale data set using numerical approach is necessary.

Floristic spectrum and higher cover values of species such as Caltha palustris, Carex appropinquata, C. elongata and Thelypteris palustris in relevé no. I is interesting from syntaxonomical point of view. There is well-established oligotrophic alder carr vegetation with marsh fern (Thelypteris palustris) in Europe (Prieditis 1993, Willner \& Grabherr 2007). Although analogous forests have been recorded under different names, this community was firstly described as an association Thelypterido palustris-Alnetum glutinosae by Klika (1940) from the Czech Republic. Species-poor herb layer, acidophilous and mire plants along with Sphagnum species, which are completely lacking in our relevé, represent diagnostic features of this association (cf. Klika l. c., Douda 2008). Their absence in combination with constant presence of typical marshland species indicates its relation to the Carici elongatae-Alnetum glutinosae.

Habitat qualities of the riparian streamside forests are strongly influenced by periodic floods during the spring and by markedly declining water table in vegetation period (Neuhäuslová 2000, Ellenberg 2009). Seasonal fluctuation of groundwater table, affecting large variability in soil moisture, results in mixed appearance of forest mesophilous and slightly hygrophilous species (Table 2) typical for the association Stellario nemorum-Alnetum glutinosae (Neuhäuslová \& Kolbek 1993). It belongs to the most frequently documented Alnion incanae community in the colline and submontane zones of Central Europe (Pott 1992, Willner \& Grabherr 2007, Douda 2008, Matuszkiewicz 2012), including also Slovakia (e.g. Miadok 1978, Kontriš 1981, Hrivnák et al. 2009, Slezák et al. 2011). In Hungarian phytosociological literature, analogous forest vegetation type has usually been mentioned as Aegopodio-Alnetum glutinosae V. Kárpáti, I. Kárpáti et Jurko ex Šomšák 1961 (e.g. Borhidi et al. 2012). Although this association's name was several times used for the riparian alder vegetation on mesic to humid sites along small brooks in Slovakia as well (Šomšák 1961, Kárpáti et al. 1963, Balázs 1996), preliminary analysis of our own data with those published in the above-mentioned botanical studies indicates certain overlapping with Stellario nemorum-Alnetum glutinosae in terms of species composition, physiognomy and ecology. However, to create consisting and unambiguous classification of Slovak alder woodlands, the existing relevé material from various authors should be used in accordance with the nomenclatural rules in comparative analysis (cf. Slezák et al. 2013).

\section{ACKNOWLEDGEMENTS}

The authors thank H. Vojteková and R. Požgaj for assistance during the field sampling, V. Grulich for determination and/or revision of herbarium specimens of Carex genera, D. Kúdelová for language improvement and anonymous reviewers for their comments to previous version of the manuscript. This work was supported by the Scientific Grant Agency of Slovak Republic (VEGA 2/0059/11) and by the Grant Agency of Faculty of Education in CU (GAPF 1/19/2013). 


\section{REFERENCES}

Balázs, P. 1996: Jelšiny Cerovej vrchoviny (fytocenologická charakteristika). Ochrana Prírody 14: 29-39.

Barkman, J. J., Doing, H. \& Segal, S. 1964: Kritische Bemerkungen und Vorschläge zur quantitativen Vegetationsanalyse. Acta Botanica Neerlandica 13: 394-419.

Berta, J. 1970: Waldgesellschaften und Bodenverhältnisse in der Theisstiefebene. Vegetácia ČSSR, B1: 1-372.

Borhidi, A., Kevey, B. \& Lendvai, G. 2012: Plant communities of Hungary. Akadémiai Kiadó, Budapest, 544 pp.

Botta-Dukát, Z., Chytrý, M., Hájková, P. \& Havlová, M. 2005: Vegetation of lowland wet meadows along a climatic continentality gradient in Central Europe. Preslia 77: 89-111.

Chytrý, M. 2000: Formalizované př́istupy k fytocenologické klasifikaci vegetace. Preslia 72: $1-29$.

Černá, L. \& Chytrý, M. 2005: Supervised classification of plant communities with artificial neural networks. Journal of Vegetation Science 16: 407-414.

Douda, J. 2008: Formalized classification of the vegetation of alder carr and floodplain forests in the Czech Republic. Preslia 80: 199-224.

Douda, J. 2010: The role of landscape configuration in plant composition of floodplain forests across different physiographic areas. Journal of Vegetation Science 21: 1110-1124.

Eliáš, P. 1980: Lesné spoločenstvá juhovýchodnej časti Tríbeča. Zborník Referátov 3. Zjazdu Slovenskej Botanickej Spoločnosti pri SAV. SBS \& VŠLD, Zvolen, pp. 75-79.

Eliáš, P. 2008: Syntaxonomický prehl'ad vegetácie podcelku Zobor v pohorí Tribeč. Rosalia 19: 21-31.

Ellenberg, H. 2009: Vegetation ecology of central Europe. Cambridge University Press, Cambridge, $734 \mathrm{pp}$.

Ellenberg, H., Weber, H. E., Düll, R., Wirth, W., Werner, W. \& Paulißen, D. 1992: Zeigerwerte von Pflanzen in Mitteleuropa. Scripta Geobotanica 18: 1-258.

Hennekens, S. M. \& Schaminée, J. H. J. 2001: TURBOVEG, a comprehensive data base management system for vegetation data. Journal of Vegetation Science 12: 589-591.

Hérault, B. \& Honnay, O. 2005: The relative importance of local, regional and historical fac- tors determining the distribution of plants in fragmented riverine forests: an emergent group approach. Journal of Biogeography 32: 2069-2081.

Hrivnák, R., Kochjarová, J., Blanár, D. \& Šoltés, R. 2009: Jelšové lesy na Muránskej planine zhrnutie súčasných fytocenologických poznatkov. Reussia 5 (1-2): 23-33.

Jarolímek, I., Šibík, J., Hegedüšová, K., Janišová, M., Kliment, J., Kučera, P., Májeková, J., Michálková, D., Sadloňová, J., Šibíková, I., Škodová, I., Uhlírová, J., Ujházy, K., Ujházyová, M., Valachovič, M. \& Zaliberová, M. 2008: A list of vegetation units of Slovakia. In: Jarolímek, I. \& Šibík, J. (eds.): Diagnostic, constant and dominant species of the higher vegetation units of Slovakia. Veda, Bratislava, pp. 295-329.

Kárpáti, V., Kárpáti, I. \& Jurko, A. 1963: Bachbegleitende Erlenauen im eukarpatischen und pannonischen Mittelgebirge. Biológia 18: 97-120.

Klika, J. 1940: Die Pflanzengesellschaften des Alnion-Verbandes. Preslia 18-19: 97-112.

Kliment, J. \& Watzka, R. 2000: Lesné spoločenstvá Drienčanského krasu. In: Kliment, J. (ed.): Príroda Drienčanského krasu. ŠOP SR, Banská Bystrica, pp. 191-214.

Kollár, J., Kanka, R. \& Šimonovič, V. 2005: Boggy black alder forests (alliance Alnion glutinosae Malcuit 1929) of northeastern part of the Borská nížina lowland. Phytopedon 4 (2): 1-11.

Kontriš, J. 1981: Pôdnoekologické a fytocenologické pomery lužných lesov Liptovskej kotliny. Biologické Práce 27 (3): 1-164.

Košir, P., Čarni, A., Marinšek, A. \& Šilc, U. 2013: Floodplain forest communities along the $\mathrm{Mu}$ ra River (NE Slovenia). Acta Botanica Croatica 72: 71-95.

Marhold, K. \& Hindák, F. (eds.) 1998: Zoznam nižších a vyšších rastlín Slovenska. Veda, Bratislava, $688 \mathrm{pp}$.

Matuszkiewicz, W. 2012: Przewodnik do oznaczania zbiorowisk roślinnych Polski. Wydawnictwo Naukowe PWN, Warszawa, 540 pp.

Miadok, D. 1978: Bachbegleitende Erlenbrüche im nordwestlichen Teil des Gemerské rudohorie-Gebirges. Acta Facultatis Rerum Naturalium Universitatis Comenianae, Botanica 26: 107-115.

Neuhäuslová, Z. 2000: Alnion incanae. In: Moravec, J. (ed.): Přehled vegetace České republiky, Svazek 2. Hygrofilní, mezofilní a xerofilní opadavé lesy. Academia, Praha, pp. 15-70. 
Neuhäuslová, Z. \& Kolbek, J. 1993: Variability of the association Stellario-Alnetum in the Czech Republic. Fragmenta Floristica et Geobotanica, Suppl. 2: 631-648.

Neuhäuslová-Novotná, Z. 1970: Beitrag zur Kenntnis der Waldgesellschaften der Kleinen Karpaten, Slowakei I. Phytozönologische Verhältnisse. Folia Geobotanica et Phytotaxonomica 5: 265-306.

Oberdorfer, E. 1953: Der europäische Auenwald. Beiträge zur naturkundlichen Forschung in Südwest-Deutschland 12: 23-70.

Petrášová, A., Hrivnák, R. \& Slezák, M. 2011: Bryoflóra jelšín stredného Slovenska v širších geografických a cenologických súvislostiach. Bryonora 48: 51-58.

Pott, R. 1992: Die Pflanzengesellschaften Deutschlands. Verlag Eugen Ulmer, Stuttgart, 437 pp.

Prieditis, N. 1993: Black alder swamps on forested peatlands in Latvia. Folia Geobotanica et Phytotaxonomica 28: 261-277.

Roleček, J., Tichý, L., Zelený, D. \& Chytrý, M. 2009: Modified TWINSPAN classification in which the hierarchy respects cluster heterogeneity. Journal of Vegetation Science 20: 596-602.

Sburlino, G., Poldini, L., Venanzoni, R. \& Ghirelli, L. 2011: Italian black alder swamps: Their syntaxonomic relationships and originality within the European context. Plant Biosystems 145: 148-171.

Slezák, M., Hrivnák, R. \& Petrášová, A. 2011: Syntaxonomy and ecology of black alder vegetation in the southern part of central Slovakia. Hacquetia 10(2): 115-132.

Slezák, M., Hrivnák, R., Petrášová, A. \& Dítě, D. 2013: Variability of alder-dominated forest vegetation along latitudinal gradient in Slovakia. Acta Societatis Botanicorum Poloniae 82: 25-35.
StatSoft 2001: STATISTICA. System reference. StatSoft Inc., Tulsa.

Šimanský, V. 2010: Základy pedológie (1 vydanie). SPU, Nitra, 108 pp.

Šomšák, L. 1961: Jelšové porasty Spišskogemerského rudohoria. Acta Facultatis Rerum Naturalium Universitatis Comenianae, Botanica 6: 407-459.

Šomšák, L. 2000: Alnion glutinosae Malcuit 1929 na Slovensku (Západné Karpaty). Acta Facultatis Rerum Naturalium Universitatis Comenianae, Botanica 40: 81-102.

Szmorad, F. 2011: The riparian alder forests of the Sopron Hills. Acta Silvatica \& Lignaria Hungarica 7: 109-124.

ter Braak, C. J. F. \& Šmilauer, P. 2002: CANOCO Reference manual and CanoDraw for Windows User's guide. Software for Canonical Community Ordination (version 4.5). Microcomputer Power, Ithaca, NY, 500 pp.

Tichý, L. 2002: JUICE, software for vegetation classification. Journal of Vegetation Science 13: 451-453.

Westhoff, V. \& van der Maarel, E. 1973: The Braun-Blanquet approach. In: Whittaker, R. H. (ed.): Ordination and classification of communities. Junk, The Hague, pp. 617-727.

Willner, W. \& Grabherr, G. 2007: Die Wälder und Gebüsche Österreichs. Ein Bestimmungswerk mit Tabellen. Spektrum Akademischer Verlag, Heidelberg, 302 pp.
Received 21. 12. 2012

Revision received 14. 5. 2013 Accepted 29. 5. 2013 
Table 1: Descriptive statistics and multiple comparisons of the environmental variables. Only statistically significant differences $(P<0.05)$ in post-hoc Tukey HSD test indicating by different letters are presented.

Tabela 1: Opisna statistika in primerjave rastiščnih spremenljivk. Z različnimi črkami so prikazane samo statistično značilne razlike $(P<0.05)$ v post-hoc Tukey HSD testu.

\begin{tabular}{lrrrrrrr}
\hline Environmental variable & Mean & SD & Max & Min & ClusterA & ClusterB1 & ClusterB2 \\
\hline Number of species per relevé & 55 & 12 & 74 & 29 & $40^{\mathrm{b}}$ & $58^{\mathrm{b}}$ & $63^{\mathrm{a}}$ \\
Ellenberg indicator values & & & & & & & \\
Light & 5.59 & 0.30 & 6.15 & 4.88 & 5.33 & 5.69 & 5.71 \\
Temperature & 5.27 & 0.45 & 5.53 & 3.58 & 5.35 & 5.44 & 5.02 \\
Continentality & 3.79 & 0.90 & 7.26 & 3.35 & 3.63 & 3.57 & 4.15 \\
Moisture & 6.61 & 0.38 & 7.14 & 5.85 & $6.22^{\mathrm{b}}$ & $6.70^{\mathrm{a}}$ & $6.85^{\mathrm{a}}$ \\
Soil Reaction & 6.61 & 0.22 & 6.93 & 6.23 & 6.64 & 6.72 & 6.48 \\
Nutrients & 6.26 & 0.25 & 6.73 & 5.82 & 6.40 & 6.19 & 6.23 \\
Measured environmental values & & & & & & & \\
Altitude (m) & 302 & 75 & 500 & 215 & 348 & 286 & 281 \\
Area (m ${ }^{2}$ Valley width (m) & 29345.06 & 56222.25 & 236128.00 & 4250.00 & 13061.60 & 47830.83 & 24428.83 \\
Minimum width or length (m) & 102.35 & 53.91 & 230.00 & 20.00 & 94.00 & 126.67 & 85.00 \\
Open soils (\%) & 79.94 & 57.73 & 260.00 & 30.00 & 60.80 & 105.00 & 70.83 \\
Open water (\%) & 10.71 & 9.03 & 35.00 & 0.00 & $5.40^{\mathrm{a}}$ & $7.50^{\mathrm{ab}}$ & $18.30^{\mathrm{b}}$ \\
Maximum content of Ca (\%) & 10.12 & 5.79 & 19.00 & 1.00 & 12.20 & 11.67 & 6.83 \\
$\mathrm{~N} \mathrm{content} \mathrm{(mg/l)}_{\text {pH H }{ }_{2} \mathrm{O}}^{2.85}$ & 3.48 & 10.00 & 0.50 & 3.30 & 4.58 & 0.75 \\
& 21.30 & 10.30 & 49.29 & 11.13 & 29.26 & 18.91 & 17.04 \\
\end{tabular}

Table 2: Phytosociological table of alder-dominated plant communities with dendrogram of the TWINSPAN analysis.

Tabela 2: Fitocenološka tabela rastlinskih združb s prevladujočo črno jelšo z dendrogramom TWINSPAN analize.

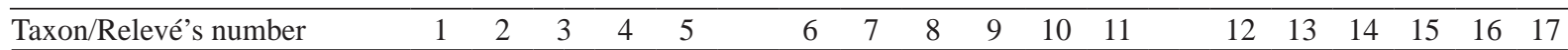

Cluster

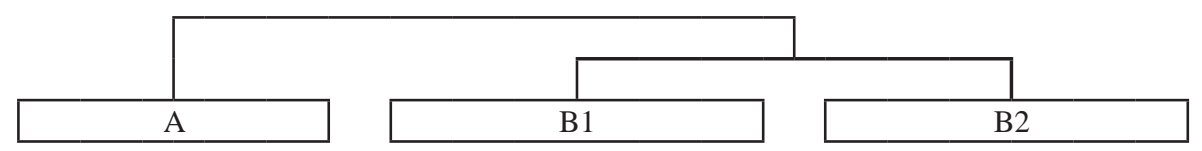

Diagnostic species of cluster A; Alnion incanae, Stellario nemorum-Alnetum glutinosae

Aegopodium podagraria

Acer campestre $\left(\mathrm{E}_{2}\right)$

Galium aparine

Pulmonaria officinalis agg.

Corylus avellana $\left(\mathrm{E}_{2}\right)$

Diagnostic species of cluster B; Alnion glutinosae, Carici acutiformis-Alnetum glutinosae

Caltha palustris

Lysimachia vulgaris

Poa trivialis

Solanum dulcamara

Lycopus europaeus

Angelica sylvestris

Festuca gigantea

Carex acutiformis

Scirpus sylvaticus

Rumex sanguineus

$\begin{array}{ccccc}\mathbf{b} & + & \mathbf{1} & \mathbf{a} & \mathbf{a} \\ + & \mathbf{a} & \mathbf{1} & \mathbf{a} & \mathbf{1} \\ \mathbf{1} & \mathbf{a} & + & + & \mathbf{a} \\ \mathbf{r} & \mathbf{1} & \mathbf{r} & \cdot & + \\ + & \mathbf{r} & \mathbf{r} & + & +\end{array}$

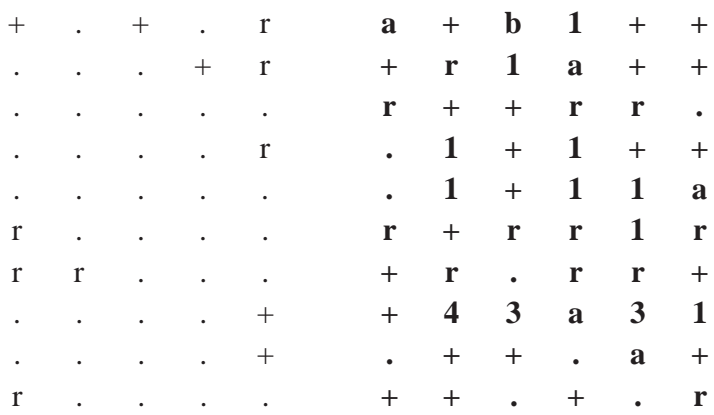

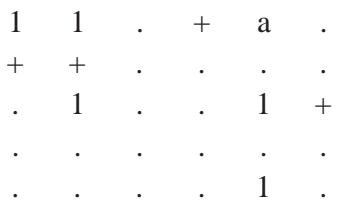

$\begin{array}{llllll}1 & \text { a } & \text { b } & \text { b } & 4 & +\end{array}$

$\mathrm{r}+\mathbf{1}+\mathbf{1}+$

r 1 b a + b

$+1+$ a a

$111+1+$

$++\mathbf{r}+\mathbf{r}$

$1+++++$

$\mathbf{r}++$ a.

1 a +1 . b

+++ r. r 


\begin{tabular}{|c|c|c|c|c|c|c|c|c|c|c|c|c|c|c|c|c|c|}
\hline Taxon/Relevé's number & 1 & 2 & 3 & 4 & 5 & 6 & 7 & 8 & 9 & 10 & 11 & 12 & 13 & 14 & 15 & 16 & 17 \\
\hline Ranunculus repens & . & . & . & . & + & . & $\mathbf{a}$ & + & + & + & • & $\mathbf{a}$ & . & $\mathbf{a}$ & 1 & + & + \\
\hline Athyrium filix-femina & . & . & 1 & . & . & . & . & . & + & + & + & . & 1 & $\mathbf{r}$ & + & $\mathbf{a}$ & + \\
\hline Rubus caesius & . & . & . & . & 1 & $\mathbf{a}$ & 1 & 1 & $\mathbf{a}$ & $\mathbf{r}$ & . & . & . & . & 1 & + & + \\
\hline Plagiomnium undulatum $\left(\mathrm{E}_{0}\right)$ & . & . & . & . & . & . & 1 & + & 1 & . & . & + & . & . & 1 & + & + \\
\hline Valeriana dioica & . & . & . & . & . & - & $\mathbf{r}$ & 1 & - & + & - & $\mathbf{r}$ & $\mathbf{r}$ & - & $\mathbf{r}$ & + & - \\
\hline Viburnum opulus $\left(\mathrm{E}_{2}\right)$ & . & $\cdot$ & $\cdot$ & . & . & $\mathbf{r}$ & $\mathbf{a}$ & $\mathbf{r}$ & . & . & $\mathbf{r}$ & . & $\mathbf{r}$ & $\mathbf{r}$ & + & . & • \\
\hline Eupatorium cannabinum & . & . & . & . & . & $\mathbf{r}$ & 1 & a & . & + & . & $\mathbf{r}$ & 1 & . & . & - & . \\
\hline Plagiomnium affine s. lat. $\left(\mathrm{E}_{0}\right)$ & . & . & . & . & . & . & + & 1 & . & . & . & + & + & . & . & + & + \\
\hline
\end{tabular}

Diagnostic species of cluster B1; Carici acutiformis-Alnetum glutinosae, variant with Ligustrum vulgare

Fraxinus excelsior $\left(\mathrm{E}_{2}\right)$

Humulus lupulus

Ligustrum vulgare $\left(\mathrm{E}_{2}\right)$

Diagnostic species of cluster B2; Carici acutiformis-Alnetum glutinosae, variant with Galium palustre

Lapsana communis

Myosotis scorpioides agg.

Juncus effusus

Persicaria hydropiper

Carex remota

Galium palustre

Veronica beccabunga

Cardamine amara

Cerastium lucorum

Galeopsis speciosa

Tree layer $\left(\mathrm{E}_{3}\right)$

Alnus glutinosa

Salix fragilis

Shrub layer $\left(\mathrm{E}_{2}\right)$

Sambucus nigra

Crataegus monogyna

Euonymus europaeus

Prunus spinosa

Swida sanguinea

Acer pseudoplatanus

Carpinus betulus

Malus sylvestris

Ribes rubrum

Herb layer $\left(\mathbf{E}_{1}\right)$

Urtica dioica

Glechoma hederacea

Impatiens noli-tangere

Geum urbanum

Circaea lutetiana

Brachypodium sylvaticum

Lysimachia nummularia

Geranium robertianum

Equisetum arvense

Stachys sylvatica

Ajuga reptans

Cirsium oleraceum

Filipendula ulmaria

Impatiens parviflora

Alliaria petiolata

$\begin{array}{cccccc}\cdot & + & \mathbf{r} & 1 & \mathbf{r} & \mathbf{r} \\ + & 1 & \mathbf{r} & \cdot & \mathbf{r} & + \\ \mathbf{r} & 1 & \mathbf{r} & + & \mathbf{r} & \mathbf{r}\end{array}$

glutinosae, variant with Galium palustre

$\begin{array}{cccccc}\mathbf{r} & + & \mathbf{r} & \mathbf{r} & . & \mathbf{r} \\ \mathbf{1} & \mathbf{b} & \mathbf{1} & \mathbf{1} & \mathbf{1} & + \\ . & \mathbf{r} & \mathbf{r} & + & \mathbf{r} & + \\ \mathbf{1} & \mathbf{3} & \mathbf{1} & \mathbf{b} & + & \mathbf{1} \\ \mathbf{1} & \mathbf{b} & \mathbf{1} & \mathbf{a} & + & \mathbf{a} \\ \cdot & \mathbf{1} & + & + & \mathbf{r} & \mathbf{1} \\ + & + & \mathbf{a} & + & \mathbf{r} & \mathbf{r} \\ \mathbf{r} & \mathbf{a} & . & \mathbf{b} & . & \mathbf{1} \\ \mathbf{r} & + & \mathbf{r} & + & \mathbf{r} & + \\ \mathbf{r} & \mathbf{1} & \mathbf{r} & \mathbf{1} & \mathbf{1} & + \\ & & & & & \\ 5 & 5 & 5 & 5 & 5 & 5 \\ . & \mathbf{r} & . & . & . & .\end{array}$

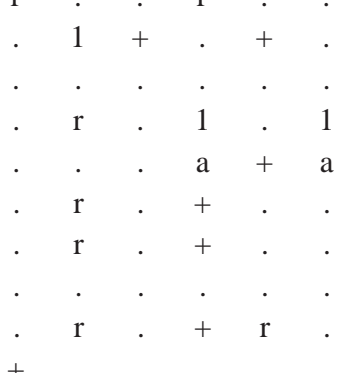

$\begin{array}{llllll}5 & 5 & 5 & 5 & 5 & 5\end{array}$

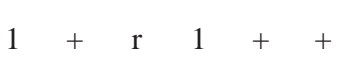

+1 . a r +

$+\quad+r$ r r.

$\begin{array}{llllll}r & r & & & & \end{array}$

$\mathrm{r} \cdot 1 .+$

$\begin{array}{cccccc}\cdot & \cdot & 1 & \cdot & \cdot & . \\ \mathrm{r} & \cdot & \cdot & + & \cdot & \cdot \\ \cdot & \cdot & \cdot & \mathrm{r} & \cdot & \cdot \\ . & + & \mathrm{r} & . & + & .\end{array}$ 


\begin{tabular}{|c|c|c|c|c|c|c|c|c|c|c|c|c|c|c|c|c|c|}
\hline Taxon/Relevé's number & 1 & 2 & 3 & 4 & 5 & 6 & 7 & 8 & 9 & 10 & 11 & 12 & 13 & 14 & 15 & 16 & 17 \\
\hline Lamium maculatum & $\mathrm{a}$ & $\mathrm{a}$ & . & . & . & + & + & . & . & 1 & . & + & + & . & + & . & + \\
\hline Rubus idaeus & . & + & . & a & + & $\mathrm{r}$ & . & + & $\mathrm{a}$ & . & + & . & . & . & + & + & . \\
\hline Deschampsia cespitosa & . & . & . & $\mathrm{a}$ & . & + & $\mathrm{r}$ & 1 & . & . & $\mathrm{r}$ & + & . & 1 & . & $\mathrm{r}$ & . \\
\hline Dryopteris carthusiana & . & . & . & $\mathrm{r}$ & . & $\cdot$ & + & . & 1 & $\mathrm{r}$ & $\mathrm{r}$ & . & . & . & + & + & + \\
\hline Chrysosplenium alternifolium & + & . & 1 & . & . & . & . & . & + & . & . & 1 & + & . & . & + & $\mathrm{a}$ \\
\hline Acer campestre & + & . & . & . & . & $\mathrm{r}$ & $\mathrm{r}$ & $\mathrm{r}$ & . & $\mathrm{r}$ & . & . & . & $\mathrm{r}$ & . & . & . \\
\hline Petasites hybridus & . & 3 & . & . & . & . & . & $\mathrm{r}$ & . & . & . & $\mathrm{r}$ & + & . & . & $\mathrm{b}$ & . \\
\hline Viburnum opulus & + & . & . & + & . & . & . & . & . & + & . & . & $\mathrm{r}$ & . & . & . & . \\
\hline Carex sylvatica & . & $\mathrm{r}$ & . & . & . & . & $\mathrm{r}$ & . & . & . & . & + & . & . & . & + & . \\
\hline Oxalis acetosella & . & . & $\mathrm{r}$ & . & . & $\cdot$ & . & . & $r$ & . & . & . & . & . & r & r & . \\
\hline Poa palustris & . & . & . & + & . & . & . & . & . & . & . & . & . & + & . & + & $\mathrm{b}$ \\
\hline Myosoton aquaticum & . & . & . & . & + & $\cdot$ & . & . & . & . & . & . & 1 & $\mathrm{r}$ & . & $\cdot$ & $\mathrm{r}$ \\
\hline Euonymus europaeus & . & . & . & . & . & + & . & . & . & + & $\mathrm{r}$ & . & . & $\mathrm{r}$ & . & . & . \\
\hline Lythrum salicaria & . & . & . & . & . & . & $\mathrm{r}$ & + & . & . & . & . & + & . & r & . & . \\
\hline Scrophularia umbrosa & . & . & . & . & . & . & . & $\mathrm{r}$ & . & . & . & $r$ & + & + & . & . & . \\
\hline Scutellaria galericulata & . & $\cdot$ & . & . & . & . & . & . & + & $\mathrm{r}$ & $r$ & $r$ & . & $\cdot$ & . & . & . \\
\hline Epilobium roseum & . & . & . & . & . & . & . & . & + & . & $r$ & + & . & $r$ & . & . & . \\
\hline Dryopteris dilatata & . & . & . & . & . & . & . & . & . & + & . & . & + & r & . & . & + \\
\hline \multicolumn{18}{|l|}{ Moss layer $\left(\mathrm{E}_{0}\right)$} \\
\hline Brachythecium rutabulum & 1 & . & + & 1 & + & + & . & . & + & 1 & . & . & $\mathrm{r}$ & . & + & . & . \\
\hline Eurhynchium hians & + & + & . & . & $\mathrm{r}$ & . & 1 & + & + & . & + & + & . & + & . & . & . \\
\hline Brachythecium rivulare & . & + & . & . & . & $\cdot$ & . & . & . & . & . & + & . & . & . & 1 & + \\
\hline Amblystegium serpens & . & . & . & + & + & + & . & . & . & . & . & . & . & 1 & . & . & . \\
\hline Atrichum undulatum & . & . & . & . & . & + & . & . & + & . & . & . & . & . & + & + & . \\
\hline
\end{tabular}

Species occurring in less than four $(\leq 3)$ phytosociological relevés:

$\mathbf{E}_{3}$ : Acer campestre (10, r), Fraxinus excelsior (2, 2a), Populus tremula $(5,+)$, Salix caprea $(2,+)$, Ulmus minor $(10,+)$.

$\mathbf{E}_{2}$ : Acer platanoides (9, r), Alnus glutinosa $(8,+; 13,+; 14, \mathrm{r})$, Cerasus avium (4, r; 8, r; 15, +), Crataegus laevigata (12, r), Frangula alnus $(7,+; 17, \mathrm{r})$, Lonicera xylosteum $(8,+)$, Padus avium (4, r; 7, 2a; 9, r), Rhamnus catharticus (6, r; 13, r), Rosa canina agg. (9, r; 13, r; 15, r), Salix cinerea (8, $+; 12, \mathrm{r})$, S. fragilis $(8, \mathrm{r} ; 10, \mathrm{r})$, Tilia cordata $(9, \mathrm{r} ; 12, \mathrm{r})$, Ulmus glabra (8, r), U. minor (10, r; 11, r).

$\mathbf{E}_{\mathbf{1}}$ : Acer pseudoplatanus (7, r), Aethusa cynapium $(2,1 ; 13,+)$, Alisma plantago-aquatica (14, r; 17, r), Asarum europaeum $(2,1)$, Astrantia major (16, r), Bidens frondosa (11, r; $14,2 \mathrm{~b} ; 17,+)$, B. tripartita $(9,+; 12, \mathrm{r} ; 14, \mathrm{r})$, Calamagrostis epigejos $(15, \mathrm{r})$, Callitriche sp. $(17,+)$, Calystegia sepium $(7,+; 10, r)$, Cardamine flexuosa $(13, r ; 16, r)$, Cardamine impatiens $(5, \mathrm{r} ; 13,2 \mathrm{a} ; 14,+)$, Cardamine pratensis agg. (9, +; 11, +), Carduus crispus $(2,1 ; 13, \mathrm{r})$, Carex acuta $(3,+)$, C. flava agg. $(15, \mathrm{r})$, C. nigra $(4,+)$, C. paniculata $(8,2 \mathrm{a}$; $13,2 \mathrm{~b})$, C. pendula $(12,1)$, Chaerophyllum aromaticum $(2$, 2b; $12,+)$, Chelidonium majus $(2, \mathrm{r})$, Chenopodium album agg. (17, r), C. polyspermum (14, r), Corylus avellana (4, r), Crataegus monogyna $(6,+)$, Crepis paludosa $(8,1 ; 16$, +), Cucubalus baccifer (7, r; 10, r), Dactylis polygama (4, $\mathrm{r} ; 8, \mathrm{r})$, Dryopteris filix-mas $(4, \mathrm{r} ; 7, \mathrm{r})$, Epilobium ciliatum $(11, \mathrm{r})$, E. parviflorum $(14, \mathrm{r})$, E. tetragonum $(14,+)$, Equisetum fluviatile $(13, \mathrm{r})$, E. palustre $(8, \mathrm{r})$, Fagus sylvatica (2, r), Fallopia dumetorum (11, r; 13, +), Fragaria vesca (8, r), Fraxinus excelsior $(6, \mathrm{r} ; 11,+)$, Galeobdolon luteum $(3,1)$, Galeobdolon montanum (2, +; 15, r; 16, 3), Galeopsis bifida $(3, \mathrm{r} ; 11, \mathrm{r})$, Galinsoga urticifolia $(12, \mathrm{r})$, Galium odoratum $(7,+; 9, \mathrm{r})$, G. rivale $(13,+)$, Geranium palustre $(15, \mathrm{r}), \mathrm{G}$. phaeum (2, 2a), Glyceria fluitans $(9,1 ; 15, \mathrm{r} ; 17, \mathrm{r})$, Holcus lanatus (8, r; 13, r; 17, r), Iris pseudacorus (1, r; 11, +; $12,+)$, Lysimachia nemorum $(2,+; 3,+)$, Malus sylvestris $(12, \mathrm{r})$, Melica uniflora $(11, \mathrm{r})$, Mentha aquatica $(7,1), M$. arvensis $(14,+), M$. longifolia $(8, r)$, Mercurialis perennis $(9, \mathrm{r})$, Milium effusum $(4, \mathrm{r} ; 16,+)$, Moehringia trinervia $(13, \mathrm{r} ; 17, \mathrm{r})$, Mycelis muralis $(9, \mathrm{r} ; 15, \mathrm{r})$, Persicaria dubia $(13, \mathrm{r} ; 14,+)$, P. maculosa $(10, \mathrm{r} ; 11, \mathrm{r})$, Phalaroides arundinacea $(13, r)$, Phragmites australis $(7,+)$, Plantago major $(14, \mathrm{r})$, Poa nemoralis $(4, \mathrm{r} ; 11, \mathrm{r})$, Prunella vulgaris $(15, \mathrm{r})$, Quercus cerris (4, r; 9, r), Q. dalechampii $(4, \mathrm{r})$, Q. robur $(4$, $\mathrm{r} ; 6, \mathrm{r})$, Ranunculus auricomus agg. $(4, \mathrm{r} ; 17, \mathrm{r})$, R. lanuginosus $(12,1 ; 13, \mathrm{r})$, R. sceleratus $(14,+)$, Ribes rubrum (6, r), Roegneria canina (2, r; 13, +), Rorippa palustris (12, r; $14,+)$, Rosa canina agg. (6, r; 14, r), Rumex obtusifolius $(12, r)$, Sambucus nigra $(14,+)$, Senecio germanicus $(4,+)$, S. ovatus (2, r), Sonchus asper (14, r), Sorbus aucuparia $(4, r)$, Sparganium erectum $(14, r)$, Stellaria alsine $(15, r$; $17,+)$, S. holostea $(9, \mathrm{r})$, S. media $(9, \mathrm{r} ; 11,+)$, Symphytum officinale $(10, r)$, Swida sanguinea $(7,+; 14, \mathrm{r})$, Torilis japonica $(2, \mathrm{r} ; 13, \mathrm{r})$, Ulmus minor $(11, \mathrm{r})$, Valeriana officinalis $(8,+)$, Veronica chamaedrys $(2, \mathrm{r} ; 17, \mathrm{r}), \mathrm{V}$. montana $(13, \mathrm{r} ; 17, \mathrm{r})$, Vicia sepium $(16, \mathrm{r})$, Viola odorata $(15, \mathrm{r}), \mathrm{V}$. reichenbachiana $(9, \mathrm{r})$. 
$\mathbf{E}_{0}:$ Amblystegium varium $(13, \mathrm{r})$, Brachythecium salebrosum $(4,+; 7,+)$, Bryum subelegans $(4,+)$, Calliergon cordifolium $(17,+)$, Calliergonella cuspidata $(8, \mathrm{r})$, Climacium dendroides $(8, \mathrm{r})$, Cratoneuron filicinum $(12,+)$, Herzogiella seligeri $(4, \mathrm{r})$, Homalia trichomanoides $(8,+)$, Lophocolea heterophylla $(3,+; 4,+)$, Plagiomnium cuspidatum $(10,+)$, Plagiothecium denticulatum $(7,+; 16,+)$, Rhizomnium punctatum $(9,+)$.

\section{Localities of phytosociological relevés}

Relevé number, locality-village (full headers with higher accuracy location of individual relevés are presented in the Slovak Phytosociological Database; http://ibot.sav.sk/cdf/ index.html), altitude (m), aspect (in letters), slope (degrees), relevé area, cover of tree layer $\left(\mathrm{E}_{3}\right)$, cover of shrub layer $\left(E_{2}\right)$, cover of herb layer $\left(E_{1}\right)$, cover of mosses and lichens $\left(\mathrm{E}_{0}\right)$, longitude, latitude, date (day/month/year), relevé author.

1. Bojná, Bojnianka walley, $2 \mathrm{~km} \mathrm{NW}$ from Ranč pod Babicou (Považský Inovec Mts.), $240 \mathrm{~m},-, 0^{\circ}, 400 \mathrm{~m}^{2}, \mathrm{E}_{3} 90 \%, \mathrm{E}_{2}$ $1 \%, \mathrm{E}_{1} 98 \%, \mathrm{E}_{0} 5 \%, 18^{\circ} 015^{\prime} 09.18^{\prime \prime} \mathrm{E}, 48^{\circ} 36^{\prime} 56.24^{\prime \prime} \mathrm{N}, 24$. 07. 2011, J. Koštál.

2. Vel'ké Pole, Tomov štál, $1.5 \mathrm{~km}$ NE from village Velké Pole (Vtáčnik Mts.), $500 \mathrm{~m},-, 0^{\circ}, 400 \mathrm{~m}^{2}, \mathrm{E}_{3} 90 \%, \mathrm{E}_{2} 20 \%$, $\mathrm{E}_{1} 95 \%, \mathrm{E}_{0} 2 \%, 18^{\circ} 34^{\prime} 35.20^{\prime \prime} \mathrm{E}, 48^{\circ} 32^{\prime} 52.28^{\prime \prime} \mathrm{N}, 19.07$. 2011, J. Koštál.

3. Kostolany pod Tribečom, Babova walley, $800 \mathrm{~m} \mathrm{NE}$ from the Jedliny (Tribeč Mts.), $300 \mathrm{~m},-, 0^{\circ}, 400 \mathrm{~m}^{2}, \mathrm{E}_{3} 95 \%, \mathrm{E}_{2}$ $8 \%, \mathrm{E}_{1} 90 \%, \mathrm{E}_{0} 5 \%, 18^{\circ} 14^{\prime} 11.19^{\prime \prime} \mathrm{E}, 48^{\circ} 26^{\prime} 25.31^{\prime \prime} \mathrm{N}, 27$. 07. 2011, J. Koštál.

4. Jedlové Kostolany, Žitava walley, on the confluence with Žitavica (Tribeč Mts.), $400 \mathrm{~m},-, 0^{\circ}, 400 \mathrm{~m}^{2}, \mathrm{E}_{3} 90 \%, \mathrm{E}_{2}$ $2 \%, \mathrm{E}_{1} 100 \%, \mathrm{E}_{0} 5 \%, 18^{\circ} 31^{\prime} 56.16^{\prime \prime} \mathrm{E}, 48^{\circ} 28^{\prime} 23.79^{\prime \prime} \mathrm{N}, 19$. 07. 2011, J. Koštál, H.Vojteková \& R. Požgaj.

5. Horné Hámre, Brod, Pílanský stream, $1.5 \mathrm{~km}$ SWW from Brod (Vtáčnik Mts.), $300 \mathrm{~m},-, 0^{\circ}, 400 \mathrm{~m}^{2}, \mathrm{E}_{3} 95 \%, \mathrm{E}_{2} 5 \%$, $\mathrm{E}_{1} 90 \%, \mathrm{E}_{0} 2 \%, 18^{\circ} 38^{\prime} 41.30^{\prime \prime} \mathrm{E}, 48^{\circ} 30^{\prime} 03.87^{\prime \prime} \mathrm{N}, 19.07$. 2011, J. Koštál, H.Vojteková \& R. Požgaj.

6. Kolačno, water reservoir (Tribeč Mts.), $250 \mathrm{~m},-, 0^{\circ}$, $400 \mathrm{~m}^{2}, \mathrm{E}_{3} 90 \%, \mathrm{E}_{2} 15 \%, \mathrm{E}_{1} 95 \%, \mathrm{E}_{0} \%, 18^{\circ} 24^{\prime} 37.88^{\prime \prime} \mathrm{E}$, $48^{\circ} 35^{\prime} 11.55^{\prime \prime}$ N, 22. 07. 2011, J. Koštál, H. Vojteková\& R. Požgaj.

7. Brodzany, Brodziansky stream, $2 \mathrm{~km}$ SE from Brodzany (Tribeč Mts.), $240 \mathrm{~m},-, 0^{\circ}, 400 \mathrm{~m}^{2}, \mathrm{E}_{3} 90 \%, \mathrm{E}_{2} 30 \%, \mathrm{E}_{1}$ $90 \%, \mathrm{E}_{0} 10 \%, 18^{\circ} 21^{\prime} 27.65^{\prime \prime} \mathrm{E}, 48^{\circ} 35^{\prime} 40.20^{\prime \prime} \mathrm{N}, 07.07$. 2011, J. Koštál.

8. Píla, Pílanský stream, 1 km NW from Píla (Vtáčnik Mts.), $400 \mathrm{~m},-, 0^{\circ}, 450 \mathrm{~m}^{2}, \mathrm{E}_{3} 80 \%, \mathrm{E}_{2} 15 \%, \mathrm{E}_{1} 95 \%, \mathrm{E}_{0}$ 5\%, $18^{\circ} 35^{\prime} 01.67^{\prime \prime}$ E, $48^{\circ} 31^{\prime} 32.86^{\prime \prime}$ N, 09. 07. 2011, J. Koštál.

9. Kostolany pod Tribečom, by Drevenica stream, $1.2 \mathrm{~km} \mathrm{~N}$ from Jedliny (Tribeč Mts.), $330 \mathrm{~m},-, 0^{\circ}, 400 \mathrm{~m}^{2}, \mathrm{E}_{3} 90 \%$, $\mathrm{E}_{2} 20 \%, \mathrm{E}_{1} 85 \%, \mathrm{E}_{0} 5 \%, 18^{\circ} 13^{\prime} 23.46^{\prime \prime} \mathrm{E}, 48^{\circ} 26^{\prime} 35.58^{\prime \prime} \mathrm{N}$, 27. 07. 2011, J. Koštál.

10. Tesáre, Zlavský stream, $0.5 \mathrm{~km}$ NW from water reservoir Tesáre (Považský Inovec Mts.), $215 \mathrm{~m},-$, $0^{\circ}$, $400 \mathrm{~m}^{2}, \mathrm{E}_{3} 80 \%, \mathrm{E}_{2} 5 \%, \mathrm{E}_{1} 95 \%, \mathrm{E}_{0} 7 \%, 18^{\circ} 04^{\prime} 28.93 " \mathrm{E}$, $48^{\circ} 36^{\prime} 52.95^{\prime \prime}$ N, 22. 07. 2011, J. Koštál, H. Vojteková \& R. Požgaj.
11. Kostolany pod Tribečom, Jedliny, by Drevenica stream (Tribeč Mts.), $280 \mathrm{~m},-, 0^{\circ}, 450 \mathrm{~m}^{2}, \mathrm{E}_{3} 95 \%, \mathrm{E}_{2} 5 \%, \mathrm{E}_{1} 95 \%$, $\mathrm{E}_{0} 5 \%, 18^{\circ} 13^{\prime} 19.55^{\prime \prime} \mathrm{E}, 48^{\circ} 26^{\prime} 11.37^{\prime \prime} \mathrm{N}, 27.07 .2011$, J. Koštál.

12. Bojná, Bojnianka walley, $2.5 \mathrm{~km}$ NW from Ranč pod Babicou (Považský Inovec Mts.), $245 \mathrm{~m},-, 0^{\circ}$, $400 \mathrm{~m}^{2}, \mathrm{E}_{3} 90 \%, \mathrm{E}_{2} 5 \%, \mathrm{E}_{1} 65 \%, \mathrm{E}_{0} 2 \%, 18^{\circ} 01^{\prime} 45.45^{\prime \prime} \mathrm{E}$, $48^{\circ} 37^{\prime} 14.52 " \mathrm{~N}, 24.07 .2011$, J. Koštál.

13. Hostie, Hlboká walley, Hostiansky stream, $1 \mathrm{~km} \mathrm{~N}$ from Skýcovský mlyn (Tribeč Mts.), $300 \mathrm{~m},-, 0^{\circ}, 400 \mathrm{~m}^{2}, \mathrm{E}_{3} 85 \%$, $\mathrm{E}_{2} 1 \%, \mathrm{E}_{1} 85 \%, \mathrm{E}_{0} 2 \%, 18^{\circ} 28^{\prime} 27.91^{\prime \prime} \mathrm{E}, 48^{\circ} 29^{\prime} 16.51^{\prime \prime} \mathrm{N}, 08$. 07. 2011, J. Koštál.

14. Kolačno, water reservoir (Tribeč Mts.), $250 \mathrm{~m},-, 0^{\circ}$, $400 \mathrm{~m}^{2}, \mathrm{E}_{3} 90 \%, \mathrm{E}_{2} 1 \%, \mathrm{E}_{1} 70 \%, \mathrm{E}_{0} 5 \%, 18^{\circ} 24^{\prime} 39.53 " \mathrm{E}$, $48^{\circ} 35^{\prime} 13.05^{\prime \prime}$ N, 22. 07. 2011, J. Koštál.

15. Skýcov, Uhrovská walley, Vyčoma stream (Tribeč Mts.), $310 \mathrm{~m},-, 0^{\circ}, 400 \mathrm{~m}^{2}, \mathrm{E}_{3} 90 \%, \mathrm{E}_{2} 1 \%, \mathrm{E}_{1} 75 \%, \mathrm{E}_{0} 7 \%$, $18^{\circ} 24^{\prime} 20.85^{\prime \prime}$ E, $48^{\circ} 31^{\prime} 47.61^{\prime \prime} \mathrm{N}, 12.07 .2011$, J. Koštál.

16. Vel'ké Uherce, Drahožická walley, Drahožický stream, 4 $\mathrm{km} \mathrm{S}$ from water reservoir Vel'ké Uherce (Tribeč Mts.), $350 \mathrm{~m},-, 0^{\circ}, 450 \mathrm{~m}^{2}, \mathrm{E}_{3} 85 \%, \mathrm{E}_{2} 5 \%, \mathrm{E}_{1} 85 \%, \mathrm{E}_{0} 5 \%$, $18^{\circ} 27^{\prime} 20.96^{\prime \prime}$ E, $48^{\circ} 33^{\prime} 10.17^{\prime \prime}$ N, 07. 07. 2011, J. Koštál.

17. Solčany, Lázkový stream (Tribeč Mts.), $230 \mathrm{~m},-, 0^{\circ}$, $400 \mathrm{~m}^{2}, \mathrm{E}_{3} 80 \%, \mathrm{E}_{2} 1 \%, \mathrm{E}_{1} 90 \%, \mathrm{E}_{0} 5 \%, 18^{\circ} 14^{\prime} 36.24^{\prime \prime} \mathrm{E}$, $48^{\circ} 31^{\prime}$ 03.51" N, 21. 06. 2011, J. Koštál. 